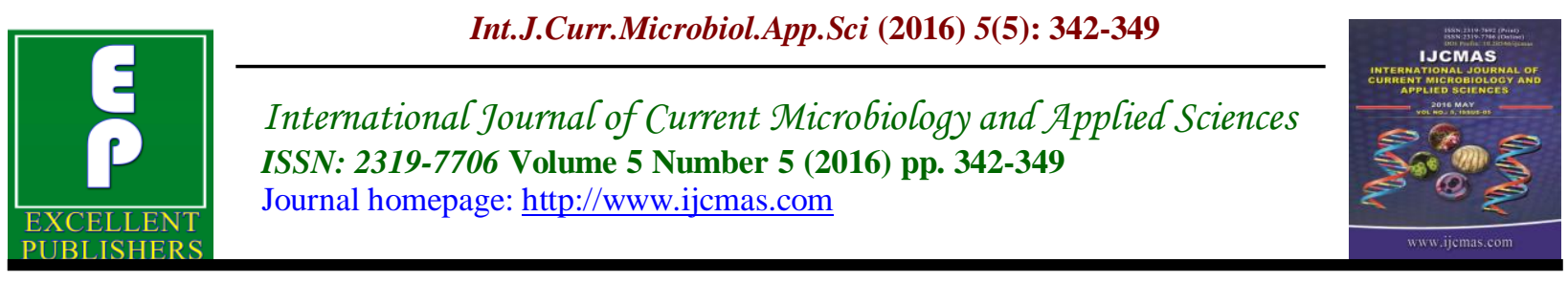

Original Research Article

http://dx.doi.org/10.20546/ijcmas.2016.505.035

\title{
Generation and Characterization of Monoclonal Antibodies Specific to Burkholderia mallei
}

\author{
Sudhir K. Dohre, Urmil Tuteja and Subodh Kumar* \\ Defence Research \& Development Establishment, Gwalior - 474002, Madhya Pradesh, India \\ *Corresponding author
}

\begin{tabular}{|c|c|}
\hline & A B S T R A C T \\
\hline $\begin{array}{l}\text { Key w o r d s } \\
\text { Burkholderia } \\
\text { mallei, } \\
\text { Glanders, } \\
\text { monoclonal } \\
\text { antibodies } \\
\text { (MoAbs). }\end{array}$ & $\begin{array}{l}\text { Glanders is a contagious disease of equines and is endemic in many countries. } \\
\text { There are problems with existing glanders diagnostic tests and monoclonal } \\
\text { antibody (MoAbs) based tests can be useful. The aim of this study was to } \\
\text { generate MoAbs specific to Burkholderia mallei. BALB/c mice were used for } \\
\text { the generation of MoAb and were injected with whole cell sonicated antigen } \\
\text { (WCS) of } B \text {. mallei. After } 3 \text { injections, two final boosts were given and spleen } \\
\text { cells of mouse showing the highest antibody titer to WCS antigen by ELISA } \\
\text { collected and fused with myeloma cells in presence of PEG } 2000 \text {. Twenty nine } \\
\text { hybridomas producing antibodies were generated of which five stable clones }\end{array}$ \\
\hline Article Info & were expanded, among them three clones were finally checked for the \\
\hline $\begin{array}{l}\text { Accepted: } \\
\text { 15 April } 2016 \\
\text { Available Online: } \\
10 \text { May } 2016\end{array}$ & $\begin{array}{l}\text { specificity of their antibodies against various Burkholderia species and other } \\
\text { closely related bacteria. Two of the MoAbs DM01BUMA01 and } \\
\text { DM01BUMA02 did not show any cross reaction with any of the tested bacteria, } \\
\text { DM01BUMA03 cross reacted with B. cenocepacia and B. gladoili. The MoAbs } \\
\text { can be utilized for detection of B. mallei. }\end{array}$ \\
\hline
\end{tabular}

\section{Introduction}

Burkholderia malle $i$ is the causative agent of glanders. Glanders is a contagious and fatal disease of horses, donkeys and mules (OIE, 2010). The disease also has high zoonotic significance and $B$. malle $i$ is listed biological warfare agent which requires handling in biosafety level-3 (BSL-3) laboratory (Wheelis, 1998). B. mallei causes nodules and ulcerations in the upper respiratory tract and lungs. A skin form also occurs, known as 'farcy'. Control of glanders requires testing of suspect clinical cases, screening of apparently normal equids, and elimination of positive reactors.
The disease has been eliminated from most countries of Western hemisphere through above mentioned countermeasures and trade restrictions. However, glanders is still endemic in Asia, Middle East, Central and South America. Recent outbreaks have occurred in many countries including India (Neubauer et al., 2005; Malik et al., 2012).

Clinical and bacteriological diagnosis of glanders is difficult in the early stages of the disease. Nearly $90 \%$ of infections exist as nonclinical or latent (Neubauer et al., 1997). Various tests for diagnosis of glanders have been described e.g. BimA based ELISA, 
complement fixation test (CFT), mallein test (Kumar et al., 2011; Khan et al., 2012). However, CFT remains one of important diagnostic tests and has been mandated by World Organization of Animal Health (OIE) as the confirmatory test for diagnosis of glanderous animal for international trade. The antibodies primarily directed against lipopolysaccharide (LPS) antigen are detected in CFT (OIE, 2010). Isolation of bacteria from lesions of diseased animal is difficult.

The monoclonal antibody (MoAb) generated by cell fusion between lymphocytes and myeloma cells is a proven useful reagent in detection and diagnosis of various diseases or their causative agents (Kohler and Milestien, 1975). Many biologists use the so-called MoAb shotgun approach, in which MoAbs are indiscriminately produced against crude immunogens, facilitating production of antibodies without any molecular information of the immunogens in advance.

Monoclonal antibody specific to $B$. mallei can be very useful in antigen based diagnosis of glanders or the detection of bacteria from non-clinical sources. Further, they can also be utilized in latex agglutination assay for quick detection of $B$. mallei culture. In this study, we report the generation and characterization of $\mathrm{MoAb}$ specific to $B$. mallei.

\section{Materials and Methods}

\section{Bacterial Cultures and Growth Conditions}

The bacterial cultures used in this study are listed in Table 1. The cultures were obtained from National Collection of Type Cultures (NCTC), Health Protection Agency, London; Microbial Type Culture Collection
(MTCC), Institute of Microbial Technology, Chandigarh or DRDE's cultures repository. $B$. mallei was grown in glycerol dextrose broth (GDB) containing peptone-10g, dextrose- $10 \mathrm{~g}$, beef extract-5g, NaCl-5g, glycerol- $40 \mathrm{ml}$ in 1 liter of distilled water for $48 \mathrm{~h}$ at $37^{\circ} \mathrm{C}$ in a shaking incubator (150 $\mathrm{rpm})$. Other bacteria were grown in the recommended media for $24 \mathrm{~h}$ at $37^{\circ} \mathrm{C}$ under shaking conditions $(150 \mathrm{rpm})$. The bacteria were enumerated by pour plate method. $B$. malle $i$ and $B$. pseudomalle $i$ cultures were grown in BSL-3 laboratory.

\section{Antigen Preparation}

Three types of antigens were prepared- (a) whole cell sonicated (WCS) antigen: The bacterial pellet was harvested by centrifugation at $8000 \mathrm{rpm}$ for $10 \mathrm{~min}$ followed by two washings and resuspension in phosphate-buffered saline (0.01 M PBS). The dissolved pellet was sonicated for $5 \mathrm{~min}$ (30 sec cycle on and $30 \mathrm{sec}$ cycle off) followed by centrifugation at $8000 \mathrm{rpm}$ for $10 \mathrm{~min}$. The supernatant was collected and sterilized by filtration $(0.45 \mu \mathrm{m}$ syringe filter, Millipore). (b) Formalin inactivated cell (FIC) antigen: For preparation of formalin inactivated cells, $2.5 \%$ formalin $(\mathrm{v} / \mathrm{v})$ was added to the bacterial growth and kept overnight at $37^{\circ} \mathrm{C}$. Overnight culture then centrifuged at $8000 \mathrm{rpm}$ for $10 \mathrm{~min}$, pellets were then washed, resuspended in equal volume of PBS. (c) Heat killed cell (HKC) antigen: The bacterial growth was kept at $80^{\circ} \mathrm{C}$ for $4 \mathrm{~h}$ in shaking $(100 \mathrm{rpm})$ water bath. The pellet was harvested by centrifugation at $8000 \mathrm{rpm}$ for $10 \mathrm{~min}$ washed and resuspended in equal volume of PBS. To further ensure that the prepared antigen was sterile, $1 \mathrm{ml}$ of each type was allowed to grow in $10 \mathrm{ml}$ of GDB or brain heart infusion (BHI) broth for 10 days at above mentioned conditions followed by plating on suitable plate medium. 


\section{Immunization}

$\mathrm{BALB} / \mathrm{c}$ mice were taken from Central Animal Facility of DRDE, Gwalior and were given water and food ad libitum. The mice were maintained and used in accordance with the recommendations of the Committee for the Purpose of Control and Supervision of Experiments on Animals (CPCSEA), Ministry of Forests and Environment, Govt. of India. The study had an approved animal protocol from Institutional Animal Ethics Committee of DRDE, Gwalior (protocol no. MB/15/51/SK). Five 6- 8 weeks old female mice were subcutaneously immunized with purified WCS of $B$. mallei strain NCTC 10229. Briefly, primary immunization was done with $25 \mu \mathrm{g}$ of purified WCS in emulsion with Freund's complete adjuvant (Sigma, USA). Two booster doses of $25 \mu \mathrm{g}$ protein with Freund's incomplete adjuvant (Sigma, USA) were followed on days 14 and 28. The antibody titer was determined by enzyme linked immunosorbent assay (ELISA) and mouse showing the highest titer was given 2 booster injections intraperitonially on consecutive days prior to sacrifice for generation of hybridomas.

\section{Generation of Monoclonal Antibodies}

Hybridoma fusions were performed to generate MoAbs, according to established procedures (Kohler and Milestien, 1975). Briefly, spleen cells from immunized BALB/c mice were fused with sp2/0-Ag.141 cells using $50 \% \mathrm{w} / \mathrm{v}$ polyethylene glycol (PEG) 2000 (Sigma Aldrich). Fused cells were grown in selective HAT-containing Dulbecco's modified Eagle's media (DMEM, Sigma) and 10\% v/v fetal bovine serum (Sigma Aldrich). The generated hybrid clones were screened for their reactivity against the antigen by indirect ELISA. Promising hybridomas were further cloned by limiting dilution method in 96 well tissue culture plates (Nunc) and resulting specific hybridomas were subjected to expansion. Supernatant of wells containing hybrids were tested for the presence of antibodies against WCS antigen of B. mallei NCTC 10229 by ELISA. Consistently positive wells were cloned and subcloned thrice to obtain stable hybrids.

\section{Enzyme Linked Immunosorbent Assay (ELISA)}

ELISA was used for screening of hybridomas, isotyping, to determine the specificity or detection limit of MoAb culture supernantant. For screening of hybridomas, ELISA modules (Nunc, maxisorp) were coated with WCS antigen (10ug/ml) in carbonate bicarbonate buffer (pH 9.6). The plate was incubated overnight at $4^{\circ} \mathrm{C}$ followed by blocking with $1 \%$ BSA at $37^{\circ} \mathrm{C}$ for $2 \mathrm{~h}$. This was followed by addition of antibodies (culture supernatant) and anti mouse IgG-HRP conjugate (1:4000) for $1 \mathrm{~h}$ each. The plate was washed 5 times after each reaction with PBS-T (0.01 M PBS with $0.05 \%$ Tween-20) reagent. The ELISA was developed with o-phenylene-diamine dihydrochloride(OPD) in citrate phosphate buffer. The reaction was stopped with $2.5 \mathrm{~N}$ $\mathrm{H}_{2} \mathrm{SO}_{4}$ and absorbance quantified at $492 \mathrm{~nm}$. For isotyping HRP-labeled goat anti-mouse IgG and IgM conjugates (BD Pharmingen) were used. The specificity of antibodies was checked against various bacteria (Table 1), which were added in $100 \mu 1\left(10^{7} \mathrm{cells} / \mathrm{ml}\right.$ FIC and HKC or $10 \mu \mathrm{g} / \mathrm{ml}$ WCS antigen) amount to the wells of ELISA modules (Nunc, maxisorp). Various antigen dilutions were used for determination of detection limit.

\section{Immunobloting}

WCS of standard strain B. mallei NCTC 10229 was prepared as described earlier and precipitated by $50 \% \quad(1: 4 \quad \mathrm{v} / \mathrm{v}) \quad$ TCA 
overnight at $4^{\circ} \mathrm{C}$. Next day precipitated WCS sample was centrifuged at 10,000 rpm for $15 \mathrm{~min}$ at $4^{\circ} \mathrm{C}$ and supernatant was discarded. The pellet was washed twice with cold acetone $+0.07 \%$ BME, air dried and dissolved in SDS sample buffer. The antigen was resolved on $12 \%$ SDS-PAGE and transferred to nitrocellulose membrane by standard Western blotting procedure. DM01BUMA01, DM01BUMA02, and DM01BUMA03 culture supernatants were used as a primary antibody with the incubation of $1 \mathrm{~h}$ at room temperature on rocker followed by reaction with antimouse-HRP conjugate as secondary antibody with the same incubation as above. Finally reaction was developed using (DAB) $-\mathrm{H}_{2} \mathrm{O}_{2}$ as substrate.

\section{Results and Discussion}

B. malle $i$ is a highly pathogenic bacterium of equines with high zoonotic potential. Many test methods have been described for diagnosis of glanders, of which CFT is mandated by OIE as confirmatory test for international trade. However, CFT has drawbacks in terms of sensitivity and specificity (Neubauer et al., 2005). Further, tests are not available for direct detection of pathogen from clinical or non-clinical samples. In this scenario, MoAb based tests can be very useful.

In the present work, efforts were made to generate MoAbs specific to $B$. mallei. Following fusion of sensitized spleen cells with myeloma cell line, 288 hybridomas were generated. These were screened for production of antibodies to WCS antigen and 29 of them were found to secrete antibodies. Five of these hybridomas were found to be stable and were expanded. However, two of the five clones did not react with FIC antigen of $B$. mallei, hence, were not taken further. Three type of antigens as described in the Materials and Methods were used. The idea of using FIC and $\mathrm{HKC}$ was that MoAb should be able to detect intact bacteria. Three clones were finally stabilized and preserved. The clones were designated as DM01BUMA01, DM01BUMA02 and DM01BUMA03. The isotyping of the generated MoAbs was determined by ELISA and DM01BUMA01, DM01BUMA02 and DM01BUMA03 were found to have IgG2b, IgG3 and IgG1 isotype respectively.

All three MoAbs were tested for specificity against different Burkholderia species and closely related bacteria by ELISA. The results are shown in Table 1. All MoAbs reacted with tested $B$. malle $i$ strains and no cross reaction was observed with $B$. pseudomallei strains. Generation of MoAbs against B. mallei and B. pseudomallei has earlier been described (Feng et al., 2006; Zao et al., 2008; Duval et al., 2014). Many of the generated MoAbs react with both the bacterial species and have been suggested to be more useful for passive protection (Jones et al., 2002; Trevino et al., 2006). It is understandable because, $B$. malle $i$ is a deletion mutant of $B$. pseudomallei and the two bacteria are $99 \%$ identical at genomic level (Godoy et al., 2003). Since the developed MoAbs are specific for B. mallei, these can be very useful for specific detection of $B$. mallei. The MoAbs except DM01BUMA03 also did not react with any other related Burkholderia or enterobacteria species. 
Table.1 Specificity of MoAbs to various antigens of Burkholderia and related species

\begin{tabular}{|c|c|c|c|c|c|}
\hline No. & Name of isolate & $\begin{array}{l}\text { Type of } \\
\text { antigen }\end{array}$ & $\begin{array}{l}\text { DM01BUMA } \\
01\end{array}$ & $\begin{array}{l}\text { DM01BUMA } \\
02\end{array}$ & $\begin{array}{l}\text { DM01BUMA0 } \\
3\end{array}$ \\
\hline \multirow[t]{3}{*}{1.} & B. mallei NCTC10229 & WCS & + & + & + \\
\hline & & FIC & + & + & + \\
\hline & & $\mathrm{HKC}$ & + & + & + \\
\hline \multirow[t]{2}{*}{2.} & B. mallei NCTC 10247 & WCS & + & + & + \\
\hline & & FIC & + & + & + \\
\hline \multirow[t]{2}{*}{3.} & B. mallei NCTC 10260 & WCS & + & + & + \\
\hline & & FIC & + & + & + \\
\hline \multirow[t]{2}{*}{4.} & B. mallei NCTC 3709 & WCS & + & + & + \\
\hline & & FIC & + & + & + \\
\hline \multirow[t]{3}{*}{5.} & B. pseudomallei NCTC 13392 & WCS & - & - & - \\
\hline & & FIC & - & - & - \\
\hline & & HKC & - & - & - \\
\hline \multirow[t]{3}{*}{6.} & B. pseudomallei DB163BUPS32 & WCS & - & - & - \\
\hline & & FIC & - & - & - \\
\hline & & $\mathrm{HKC}$ & - & - & - \\
\hline \multirow[t]{3}{*}{7.} & B. pseudomallei DB164BUPS33 & WCS & - & - & - \\
\hline & & FIC & - & - & - \\
\hline & & HKC & - & - & - \\
\hline \multirow[t]{3}{*}{8.} & Pseudomonas aeruginosa MTCC 424 & WCS & - & - & - \\
\hline & & FIC & - & - & - \\
\hline & & $\mathrm{HKC}$ & - & - & - \\
\hline \multirow[t]{3}{*}{9.} & Pseudomonas putida & WCS & - & - & - \\
\hline & DB173PSPU1 & FIC & - & - & - \\
\hline & & HKC & - & - & - \\
\hline 10. & B. серасіа МТСС 438 & $\mathrm{HKC}$ & - & - & - \\
\hline 11. & B. серасіа МТCC 1617 & $\mathrm{HKC}$ & - & - & - \\
\hline 12. & $\begin{array}{l}\text { B. сепосерасіа } 7656 \\
\text { DB174BUCE1 }\end{array}$ & $\mathrm{HKC}$ & - & - & + \\
\hline 13. & $\begin{array}{l}\text { B. cenocepacia } \\
\text { DB175BUCE2 }\end{array}$ & $\mathrm{HKC}$ & - & - & + \\
\hline 14. & B. gladioli MTCC 10216 & $\mathrm{HKC}$ & - & - & + \\
\hline 15. & B. glumae MTCC 8496 & $\mathrm{HKC}$ & - & - & - \\
\hline 16. & Cupriavidus necator MTCC 1472 & HKC & - & - & - \\
\hline 17. & Escherichia coli MTCC 739 & FIC & - & - & - \\
\hline 18. & $\begin{array}{l}\text { Salmonella typhi } \\
\text { DB177SAEN1 }\end{array}$ & FIC & - & - & - \\
\hline 19. & $\begin{array}{l}\text { Salmonella paratyphi A } \\
\text { DB178SAEN2 }\end{array}$ & FIC & - & - & - \\
\hline 20. & $\begin{array}{l}\text { Salmonella entritidis } \\
\text { DB179SAEN3 }\end{array}$ & FIC & - & - & - \\
\hline 21. & $\begin{array}{l}\text { Klebsiella pneomoniae } \\
\text { MTCC } 432\end{array}$ & FIC & - & - & - \\
\hline 22. & $\begin{array}{l}\text { Yersinia enterocolitica } \\
\text { DB176YEEN1 }\end{array}$ & FIC & - & - & - \\
\hline 23. & $\begin{array}{l}\text { Staphylococcus aureus } \\
\text { DB180STAU66 }\end{array}$ & FIC & - & - & - \\
\hline
\end{tabular}


Fig.1 Detection limit of monoclonal antibodies as determined by ELISA. A-Formalin inactivated cells (FIC) of B- Heat killed cells of B. mallei were coated on the ELISA plate at various concentrations and detected by culture supernatant of MoAb. The horizontal line shows the cut-off value.
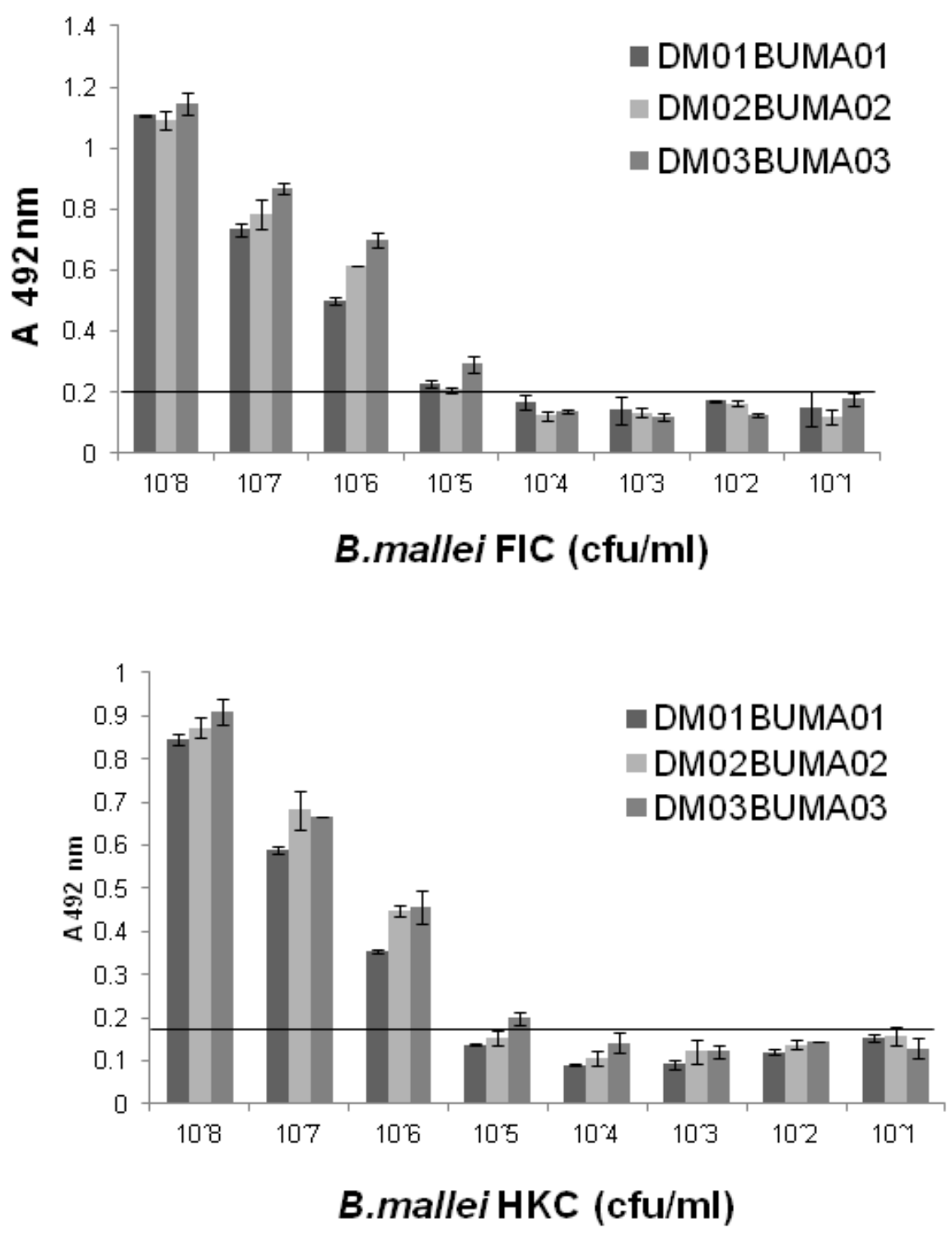
Fig.2 Western blot showing the reactivity of MoAbs with WCS antigen of B. mallei, $\mathrm{M}=$ protein marker, Lane 1: DM01BUMA01, Lane 2: DM01BUMA02, Lane 3: DM01BUMA03.

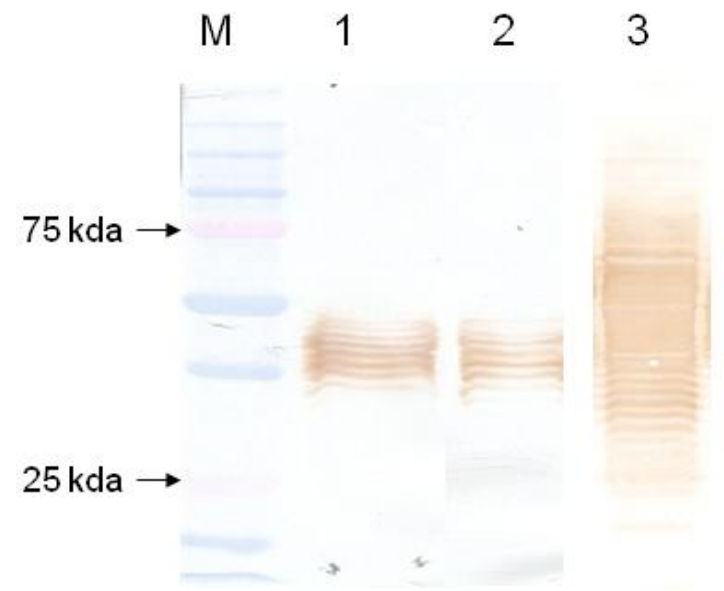

Detection limit of MoAb culture supernatant was determined by ELISA. All the MoAbs were found to detect $62.5 \mu \mathrm{g}$ of WCS antigen (results not shown). Culture supernatant of DM01BUMA01 and DM01BUMA02, MoAbs could pick up $105 \mathrm{FIC} / \mathrm{ml}$ or $10^{6} \mathrm{HKC} / \mathrm{ml}$ of $B$. mallei DM01BUMA03 was a slightly better than other two MoAbs and gave higher OD in ELISA. The detection limit of DM01BUMA03 was $10^{5} \mathrm{HKC}$ or $\mathrm{FIC} / \mathrm{ml} B$. mallei. Results are shown in Fig. 1. The WCS antigen of $B$. mallei was allowed to react with MoAbs by immunoblotting. As expected all MoAbs reacted with WCS antigen (Fig. 2). A characteristic banding pattern of lipopolysaccharide (LPS) was observed especially with DM01BUMA03, suggesting that this antibody may be directed against LPS. The MoAbs described earlier by Feng et al., 2006 also reacted with LPS.

In brief, MoAbs specific to B. malle $i$ were generated in the present work. All of these are not cross reacting with closely related $B$. pseudomallei bacteria. The MoAbs can be utilized for specific detection of $B$. mallei in clinical or non-clinical settings

\section{References}

Duval, B.D., Elrod, M.G., Gee, J.E., Chantratita, N., Tandhavanant, S., Limmathurotsakul, D., Hoffmaster, A.R. 2014. Evaluation of a latex agglutination assay for the identification of Burkholderia pseudomallei and Burkholderia mallei. Am. J. Trop. Med. Hyg., 90(6): 1043-1046.

Feng, S.H., Tsai, S., Rodriguez, J., Newsome, T., Emanuel, P., Lo, S.C. 2006. Development of mouse hybridomas for production of monoclonal antibodies specific to Burkholderia mallei and Burkholderia pseudomallei. Hybridoma (Larchmt), 25(4): 193201.

Godoy, D., Randle, G., Simpson, A.J., Aanensen, D.M., Pitt, T.L., Kinoshita, R., Spratt, B.G. 2003. Multilocus sequence typing and evolutionary relationships among the causative agents of melioidosis and glanders, Burkholderia pseudomallei and Burkholderia mallei. J. Clin. Microbiol., 41: 2068-2079. 
Jones, S.M., Ellis, J.F., Russell, P., Griffin, K.F., Oyston, P.C. 2002. Passive protection against Burkholderia pseudomallei infection in mice by monoclonal antibodies against capsular polysaccharide, lipopolysaccharide or proteins. J. Med. Microbiol., 51: 1055-1062.

Khan, I., Wieler, L.H., Melzer, F., Elschner, M.C., Muhammad, G., Ali, S., Sprague, L.D., Neubauer, H., Saqib, M. 2012. Glanders in animals: A review of epidemiology, clinical presentation, diagnosis and counter measures. Transbound Emerg. Dis., 60(3): 204-221.

Kohler, G., Milstein, C. 1975. Continuous cultures of fused cells secreting antibody of predefined specificity. Nature, 256: 495-497.

Kumar, S., Malik, P., Verma, S. K., Pal, V., Gautam, V., Mukhopadhyay, C., Rai, G.P. 2011. A recombinant Burkholderia intracellular motility A (BimA) protein for immunodiagnosis of glanders. Clin. Vaccine Immunol., 18: 1456-1461.

Malik, P., Singha, H., Khurana, S.K., Kumar, R., Kumar, S., Raut, A.A., Riyesh, T., Vaid, R.K., Virmani, N., Singh, B.K., Pathak, S.V., Parkale, D.D., Singh, B., Pandey, S.B., Sharma, T.R., Chauhan, B.C., Awasthi, V., Jain, S., Singh, R.K. 2012. Emergence and reemergence of glanders in India: a description of outbreaks from 2006-
2012. Vet. Ital., 48: 167-178.

Neubauer, H., Meyer, H., Finke, E.J. 1997. Human glanders. Rev Int. Serv. Santé Forces Armées., 70: 258265.

Neubauer, H., Sprague, L.D., Zacharia, R., Tomaso, H., Al Dahouk, S., Wernery, R., Wernery, U., Scholz, H.C. 2005. Serodiagnosis of Burkholderia mallei infections in horses: stateof-the-art and perspectives. J. Vet. Med. B Infect. Dis. Vet. Public Health., 52: 201-205.

OIE. 2010. Glanders, chapter 2.5.11. Manual of diagnostic tests and vaccines for terrestrial animals 2010. OIE, Paris, France.

Treviño, S.R., Permenter, A.R., England, M.J., Parthasarathy, N., Gibbs, P.H., Waag, D.M., Chanh, T.C. 2006. Monoclonal antibodies passively protect BALB/c mice against Burkholderia mallei aerosol challenge. Infect. Immun., 74: 19581961.

Wheelis, M. 1998. First shots fired in biological warfare. Nature, 395: 213.

Zou, N., Tsai, S., Feng, S.H., Newsome, T., Kim, H.Y., Li, B., Zhang, S., Lo, S.C. 2008. Relationship between antigenicity and pathogenicity for Burkholderia pseudomallei and Burkholderia mallei revealed by a large panel of mouse MAbs. Hybridoma (Larchmt), 27(4): 23140.

\section{How to cite this article:}

Sudhir K. Dohre, Urmil Tuteja and Subodh Kumar. 2016. Generation and Characterization of Monoclonal Antibodies Specific to Burkholderia mallei. Int.J.Curr.Microbiol.App.Sci. 5(5): 342-349. doi: http://dx.doi.org/10.20546/ijcmas.2016.505.035 